\title{
Clinicopathologic analysis of Passeriform venous blood reflects transitions in elevation and habitat
}

This article was published in the following Dove Press journal:

Veterinary Medicine: Research and Reports

5 June 2013

Number of times this article has been viewed

\section{J Jill Heatley' \\ Jennifer Cary ${ }^{2}$ \\ Karen E Russell ${ }^{3}$ \\ Gary Voelker ${ }^{2}$}

'Department of Small Animal Clinical Sciences, College of Veterinary Medicine and Biomedical Sciences, ${ }^{2}$ Department of Wildife and Fisheries Sciences and Texas A\&M Biodiversity Research and Teaching Collections, Texas A\&M University, ${ }^{3}$ Department of Pathobiology, College of Veterinary Medicine and Biomedical Sciences, College Station, TX, USA
Correspondence: J Jill Heatley

Department of Small Animal Clinical Sciences, College of Veterinary Medicine and Biomedical Sciences, Texas A\&M University, College Station,

TZ 77845-4474, USA

Tel + I979845 I202

Email jheatley@cvm.tamu.edu
Abstract: Jugular blood samples from 110 Passeriformes collected at several Texas locations were analyzed for multiple clinicopathologic parameters between April 2010 and August 2011. Electrolyte, blood gas, and select erythrocyte parameters were analyzed on site with a point of care analyzer, and gender, age, body condition score, location, and species were recorded. Many analytes exhibited a Gaussian distribution across species and are reported as a single range. Taxon affected electrolyte and red blood cell parameters, but not most blood gas or acid base variables. Migratory status affected select electrolytes but few blood gas variables. Red blood cell parameters were affected the most by variables of age, taxonomic group, and gender, but not migratory life history. We found significant changes in glucose and numerous acid base analytes in birds sampled from habitats with evolutionarily recent ecologic degradation. We advocate the use of these analytes, particularly venous blood gas values, as determined by a point of care analyzer, as reasonable biomarkers for determination of Passeriform population health, but also recommend that red blood cell parameters and electrolyte concentrations be controlled for age, species, and gender in future studies. Further, based on our investigation, venous blood gas values and acid base balance in Passeriformes can assess the health of an ecosystem.

Keywords: avian, biochemistry, blood gas, electrolyte, hematology, Passerine

\section{Introduction}

Hematology values for free-living Passeriformes are commonly investigated indicators of population health. ${ }^{1-4}$ However, study of biochemical parameters, such as enzyme activity, electrolytes, or acid base status in these species is more limited and results are equivocal. ${ }^{5-7}$ Necessary sample volume and analyzer portability have until recently been a limiting factor in these studies. Most work has relied on determination of cell counts, packed cell volume, or presence of parasites in blood smears, which require $100 \mu \mathrm{L}$ or less of blood. While cell counts are valuable immunologic parameters, they provide little or no information regarding the respiratory or cardiovascular systems, physiologic and biochemical fluid balance, or the organ health and function necessary for continued life of an organism. Determination of acid base status and electrolyte balance in the field with relatively small sample volumes and immediate results has become a practical reality with the advent of the i-STAT ${ }^{\circledR}$ system. This point of care instrument was designed for use in human intensive care units, but compares well with standard bench top analyzers in a variety of species, including chickens and Amazon parrots. ${ }^{8-10}$ This study assessed the feasibility of measuring select erythrocyte, electrolyte, venous blood gas, and acid base balance values via the i-STAT to gauge the baseline health of free-living Passeriformes from different ecosystems in Texas. 
We hypothesized that seasonal and diurnal factors and the parameters of family, gender, body condition score, age and migratory life history would minimally affect these analytes across Passeriformes. Detectable variations in these biochemical and hematologic values would therefore be real-time tools for studying the health of free-living Passeriform populations. Health could be assessed in the face of multiple causes of decline of habitat suitability, including environmental degradation or toxification, intrusion of infectious agents, or other environmental change.

\section{Materials and methods}

\section{Animal capture}

Passeriformes (Table 1, Table 2) were sampled between April and August in the years 2010-2011 from nine counties in Texas either on or east of the Edwards Plateau. Coordinates of sampling spanned 29.57.473-30.55.011 N latitude and 94.26.604-99.23.731 W longitude. Edwards Plateau counties in which we sampled birds are outlined in brown (Kerr, Comal, Hays, Travis) while nonplateau counties (Tyler, Williamson, Brazos, Bastrop, Grimes) are white (Figure 1). Birds were trapped and sampled from the months of April through August in 2010-2011. Time of day for sampling ranged from 6:45 to $20: 10$ central standard time. This research was conducted under required Texas Parks and Wildlife and United States Fish and Wildlife permits and with approval

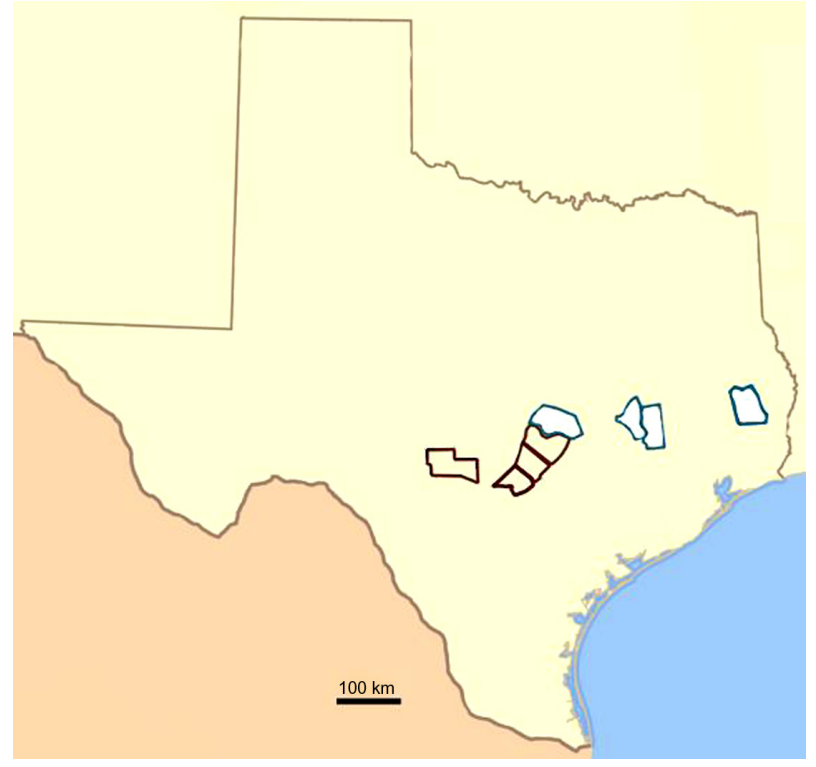

Figure I Counties of Passeriforme collections for electrolytes and venous blood gas parameters.

Notes: Counties from the Edwards Plateau are more westerly and outlined in brown while white, blue outlined, more easterly counties are not located on the Edwards Plateau. of the Texas A\&M University Institutional Animal Care and Use Committee.

\section{Animal sampling}

Birds were captured via mist net and placed in cloth bags until venipuncture could be performed. Time of capture and total time held in the bag were not recorded, but were less than 30 minutes. Birds were held in bags for at least 5 minutes to allow calming before sampling. Animals were manually restrained for collection of $0.2-0.5 \mathrm{~mL}$ of blood via jugular venipuncture with needle and syringe.

\section{Sample analysis}

Blood samples were transferred to lithium heparin microtainer tubes (Sarstedt Inc, Newton, NC, USA). Analyses were immediately performed using the i-STAT system (Abbott Laboratories. Abbott Park, IL, USA). Blood gas cartridges (CG4+ or CG8+) were analyzed first, followed by cartridges which did not analyze blood gases $(6+, \mathrm{E} 3+$, $\mathrm{E} 3+\mathrm{Cl}$ ). Cartridges were analyzed within 5 minutes of blood collection, and time of day was recorded as time of analyte results for the first cartridge. Analytes determined varied according to the cartridge ${ }^{11}$ used and blood volume obtained, and included: $\mathrm{pH}$ (venous), $\mathrm{pCO}_{2}$ (carbon dioxide partial pressure, venous), $\mathrm{pO}_{2}$ (oxygen partial pressure, venous), lactate, bicarbonate, total $\mathrm{CO}_{2}$, base excess, $\mathrm{sO}_{2}$ (dissolved oxygen, venous), ionized calcium, glucose, blood urea nitrogen, calculated hematocrit, hemoglobin, sodium, potassium, and chloride. Most values obtained by the i-STAT system are measured directly, but total $\mathrm{CO}_{2}$, base excess, hemoglobin, and $\mathrm{sO}_{2}$ are calculated. Blood was spun in lithium heparin microhematocrit tubes (StatSpin ${ }^{\circledR}$ centrifuge, Iris ${ }^{\circledR}$ sample processing, Westwood, MA, USA) for packed cell volume determination at $15,000 \mathrm{~g}$ for 3 minutes within 24 hours of blood collection. After venipuncture, a physical examination was performed and a body condition score was determined. ${ }^{12}$ Birds were then humanely killed via thoracic compression as part of a larger assessment of genetic variation and biodiversity conducted by one of the investigators (GV). Birds were prepared as standard museum specimens and deposited at the Biodiversity Research and Teaching Collections at Texas A\&M University. Species, gender, and age were, if possible, determined based on external field markings and confirmed during preparation of the specimens. Temperature corrections using an assumed Passeriform temperature of $41.3^{\circ} \mathrm{C}$ were performed for $\mathrm{pH}, \mathrm{pCO}_{2}$, and $\mathrm{pO}_{2}$ measurements. ${ }^{7,13}$ Migratory status was assigned based on known life histories. ${ }^{14}$ 


\section{Additional calculations}

We calculated the anion gap for the birds found on and off the Edwards Plateau using the formula:

$$
\text { Anion gap }=(\mathrm{Na}+\mathrm{K})-\left(\mathrm{Cl}+\mathrm{HCO}_{3}\right)
$$

\section{Statistical methods}

Data analyses were performed using statistical software (Analyse-it for Microsoft Excel ${ }^{\circledR}$ version 2.20 Microsoft Office 2010, Analyse-it ${ }^{\circledR}$ Software Ltd, http://www. analyse-it.com/, 2009), and temperature was corrected for by using formulas in the i-STAT manual. Normality for each analyte for all samples was assessed by histogram and the Shapiro-Wilk test $(P>0.05)$. The effect of family was assessed by one-way analysis of variance for families with at least seven members sampled, ie, Vireonidae, Troglodytidae, Parulidae, Paridae, Emberizidae, and Cardinalidae. Ionized calcium was not assessed for effect of taxonomic group based on small sample sizes. The effect of gender, age, location, and migratory life history were assessed using the Kruskal-Wallis test, with $P<0.05$ considered to be statistically significant. The effect of time of day and date on all variables and the effect of lactate on $\mathrm{pH}$ were assessed by linear regression. In 53 birds, we assessed the effect of a result of $<3$ or $\geq 3$ for blood urea nitrogen on the analytes of sodium, potassium, chloride, hematocrit, hemoglobin, and packed cell volume using the Kruskal-Wallis test. The effect of body condition score on all analytes was assessed using one-way analysis of variance, with $P<0.05$ considered to be statistically significant. The agreement between packed cell volume as measured by centrifugation and hematocrit as measured by the iSTAT was assessed using the Bland-Altman plot.

\section{Results}

Passerine birds $(\mathrm{n}=110)$ from 11 families were sampled and collected, with most being Paridae (Table 1). Both migratory and nonmigratory species were collected (Table 2). When analyzed as a single population for all birds at all sites, most analytes were parametrically distributed except for blood urea nitrogen, glucose, hematocrit, packed cell volume, and $\mathrm{pO}_{2}$ (Table 3). Chloride and glucose concentrations were higher in birds captured on Edwards Plateau, while bicarbonate, base excess, $\mathrm{pH}$, percent $\mathrm{sO}_{2}$, and total $\mathrm{CO}_{2}$ were lower in birds sampled from this plateau when compared with birds sampled east of this geologic formation (Table 4). Gender was determined for 105 birds, but for the remaining five, we were unable to determine gender
Table I Summary of I I0 Passeriformes sampled for electrolytes and venous blood gases using the i-STAT ${ }^{\circledR}$ system

\begin{tabular}{llllll}
\hline Family & Total & Males & Females & Adult & Juvenile \\
\hline Paridae & $39^{\mathrm{a}}$ & 19 & 18 & 20 & 18 \\
Troglodytidae & $25^{\mathrm{b}}$ & 13 & 10 & 13 & $1 \mathrm{1}$ \\
Cardinalidae & 12 & 8 & 4 & 12 & 0 \\
Vireonidae & 9 & 6 & 3 & $\mathrm{I}$ & 0 \\
Emberizidae & 7 & 1 & 6 & 7 & 0 \\
Parulidae & 9 & 5 & 3 & 8 & 0 \\
Tyrannidae & 4 & 3 & $\mathrm{I}$ & 3 & $\mathrm{I}$ \\
Corvidae & 2 & 0 & 1 & 1 & 1 \\
Fringillidae, & 3 & 2 & 0 & 2 & 0 \\
Turdidae, Mimidae & & & & & \\
Plateau & 52 & 27 & 25 & 30 & 22 \\
Non-plateau & 52 & 32 & 20 & 37 & 15 \\
Totals & 110 & 59 & 47 & 69 & 40
\end{tabular}

Notes: ane unknown age, two unknown gender; ${ }^{b}$ two unknown gender, one unknown age.

based on age and time between capture and specimen preparation (indistinct gonads, five birds) or inadvertent release (one bird).

Hematocrit and hemoglobin were higher in males than in females, while glucose concentration was higher in females (Table 5). Taxonomic grouping affected electrolyte concentrations (values given as $\mathrm{n}$ for the analyte and $P$ for analysis of variance): sodium (83, 0.0008), chloride $(59,0.0006)$, potassium $(83,0.0317)$, and hematologic variables measured by the i-STAT, hemoglobin (83, 0.0035), hematocrit (83, 0.0029), $\mathrm{pO}_{2}(85,0.0088)$, and glucose $(77,0.0363)$. Adult birds had higher hematocrit, base excess, hemoglobin, bicarbonate, and total $\mathrm{CO}_{2}$, while juveniles had higher lactate concentrations (Table 6). Migratory birds had increased $\mathrm{pO}_{2}$, percent $\mathrm{sO}_{2}$, and chloride, and lower total $\mathrm{CO}_{2}$, bicarbonate, and sodium than nonmigratory birds (Table 7). Logistic regression failed to reveal evidence of diurnal or seasonal variation in any analyte when all samples were included. For blood urea nitrogen, 17 of 54 birds sampled for this analyte measured $\geq 3 \mathrm{mg} / \mathrm{dL}$, which is the lower limit of quantification for this assay. When blood urea nitrogen was $\geq 3$, hematocrit $(P=0.0278)$ and hemoglobin $(P=0.0278)$ increased and packed cell volume also trended towards an increase $(P=0.0525)$. Lactate had no measurable effect on $\mathrm{pH}\left(\mathrm{R}^{2}=0.01, P=0.8660\right)$. Body condition score (BCS) was determined for 60 birds and was associated with an increased blood urea nitrogen concentration in BCS two and four birds (n $=40, P=0.0201$ ). A Bland-Altman plot showed poor agreement for packed cell volume and hematocrit (Figure 2). The anion gap for mean values of birds captured on the plateau was 12.56 and for those off the plateau was 4.076. 
Table 2 Passeriformes collected for clinicopathologic analysis of venous blood

\begin{tabular}{|c|c|c|c|}
\hline Migratory species & $n=29$ & Nonmigratory species & $\mathbf{n}=\mathbf{8 I}$ \\
\hline Common name & Scientific name & Common name & Scientific name \\
\hline Bell's vireo & Vireo bellii & Bewick's Wren & Thryomanes bewickii \\
\hline Painted bunting & Passerina ciris & Northern Cardinal & Cardinalis cardinalis \\
\hline Summer tanager & Piranga rubra & Northern Mockingbird & Mimus polyglottos \\
\hline White-eyed vireo & Vireo griseus & Rufous-crowned sparrow & Aimophila ruficeps \\
\hline Yellow-bellied fly catcher & Empidonax flaviventris & Tufted Titmouse & Baeolophus bicolor \\
\hline Yellow-breasted chat & Icteria virens & Western Scrub jay & Aphelocoma californica \\
\hline Yellow-throated vireo & Vireo flavifrons & Black-crested titmouse & Baeolophus atricristatus \\
\hline Eastern Phoebe & Sayornis phoebe & Carolina chickadee & Poecile carolinensis \\
\hline Field sparrow & Spizella pusilla & Carolina wren & Thryothorus ludovicianus \\
\hline Hermit thrush & Catharus guttatus & Chipping sparrow & Spizella passerina \\
\hline Hooded warbler & Setophaga citrina & House finch & Haemorhous mexicanus \\
\hline Orange-crowned warbler & Oreothlypis celata & & \\
\hline
\end{tabular}

\section{Discussion}

Hematocrit and hemoglobin were affected by age, taxonomic group, and gender, although values were similar to those reported in other Passeriformes. ${ }^{1,2,4,15}$ The increased hematocrit and hemoglobin of male and adult birds were expected changes previously reported for Passeriformes. ${ }^{16,17}$ Packed cell volume

Table 3 Electrolyte and venous blood gas reference intervals for Passeriformes from Texas

\begin{tabular}{|c|c|c|c|c|c|}
\hline Analyte & Units & $\begin{array}{l}\text { Birds } \\
\text { sampled }\end{array}$ & Mean & $95 \% \mathrm{Cl}$ & $P$ value \\
\hline Base excess & $\mathrm{mmol} / \mathrm{L}$ & 91 & 2.74 & $1.8-3.7$ & 0.619 \\
\hline BUN* & $\mathrm{mmol} / \mathrm{L}$ & 55 & 1.18 & $0.96-1.39$ & $<0.0001$ \\
\hline Chloride & $\mathrm{mmol} / \mathrm{L}$ & 66 & 124.2 & $123.1-125.4$ & 0.220 \\
\hline Glucose* & $\mathrm{mmol} / \mathrm{L}$ & 86 & 18.59 & $|7.68-19.5|$ & 0.028 \\
\hline Bicarbonate & $\mathrm{mmol} / \mathrm{L}$ & 91 & 24.45 & $23.62-25.27$ & 0.565 \\
\hline $\mathrm{Hgb}$ & $\mathrm{g} / \mathrm{dL}$ & 92 & 141.7 & |38.5-|44.9 & 0.039 \\
\hline $\mathrm{Hct}$ & $\begin{array}{l}\text { Proportion } \\
\text { of I }\end{array}$ & 92 & 0.417 & $0.408-0.426$ & 0.057 \\
\hline $\mathrm{iCa}$ & $\mathrm{mmol} / \mathrm{L}$ & 32 & 0.268 & $0.258-0.276$ & 0.986 \\
\hline Potassium & $\mathrm{mmol} / \mathrm{L}$ & 91 & 4.10 & $3.93-4.27$ & 0.480 \\
\hline Lactate & $\mathrm{mmol} / \mathrm{L}$ & 63 & 4.55 & $4.25-4.86$ & 0.157 \\
\hline $\mathrm{pCO}_{2}$ & $\mathrm{mmHg}$ & 91 & 26.05 & $25.03-27.07$ & 0.598 \\
\hline $\mathrm{PCO}_{2 \mathrm{TC}}$ & $\mathrm{mmHg}$ & 91 & 31.40 & $30.16-32.64$ & 0.532 \\
\hline $\mathrm{PCV}^{*}$ & $\%$ & 104 & 56.7 & $55.4-58.0$ & 0.044 \\
\hline $\mathrm{pH}$ & $\begin{array}{l}\mathrm{pH} \text { at } \\
37^{\circ} \mathrm{C}\end{array}$ & 91 & 7.583 & 7.563-7.60I & 0.452 \\
\hline $\mathrm{pH}_{\mathrm{TC}}$ & $\begin{array}{l}\mathrm{pH} \text { at } \\
41.3^{\circ} \mathrm{C}\end{array}$ & 91 & 7.514 & 7.498-7.532 & 0.452 \\
\hline $\mathrm{pO}_{2} *$ & $\mathrm{mmHg}$ & 91 & 38.4 & $37.2-39.5$ & 0.004 \\
\hline $\mathrm{pO}_{2 \mathrm{TC}} *$ & $\mathrm{mmHg}$ & 91 & 51.97 & $50.4-53.5$ & 0.005 \\
\hline $\mathrm{sO}_{2}$ & $\%$ & 91 & 81.1 & $79.6-82.7$ & 0.043 \\
\hline Sodium & $\mathrm{mmol} / \mathrm{L}$ & 92 & 156.3 & $155.3-157.3$ & 0.151 \\
\hline $\mathrm{TCO}_{2}$ & $\mathrm{mmol} / \mathrm{L}$ & 91 & 25.3 & $24.5-26.2$ & 0.207 \\
\hline
\end{tabular}

Notes: Normal distribution, $P>0.05$, while analytes with non-normal distributions are denoted*. Temperature-dependent variables listed at $37^{\circ} \mathrm{C}$ and temperaturecorrected (TC subscript) to $41.33^{\circ} \mathrm{C}$.

Abbreviations: $\mathrm{TCO}_{2}$, total $\mathrm{CO}_{2}$; $\mathrm{BUN}$, blood urea nitrogen; Hct, hematocrit; $\mathrm{Hgb}$, hemoglobin; PCV, packed cell volume; $\mathrm{pO}_{2}$, oxygen partial pressure, venous; $\mathrm{sO}_{2}$, dissolved oxygen, venous; $\mathrm{iCa}$, ionized calcium. did not change according to gender. However, calculation of hematocrit by the iSTAT system appears inaccurate but more precise than PCV determination by centrifugation. We attribute this change to small sample volume and human error in processing and reading microhematocrit tubes. Thus, the i-STAT could better determine subtle population differences, while a correction factor was necessary for clinical application. Increased hematocrit and hemoglobin of certain families (Cardinalidae, Tyrannidae, Paridae) should be assessed in future studies of these families. While hematologic variables are most often assessed in studies of Passeriform health, these assays appear sensitive to multiple factors which may be difficult to account for adequately in models. Therefore, red blood cell parameters may be less amenable for evaluating population health and thereby ecosystem dysfunction. Hematocrit was consistently lower than packed cell volume by an average of $15 \%$ in the Passeriformes we sampled, and 95\% confidence intervals for these values do not overlap. This discrepancy may be based on methodology, because the i-STAT calculates hematocrit by electrical impedance measurements after correction for electrolyte concentrations. In human blood samples, hemoglobin is then derived from this value. Multiple physiologic factors of the avian red blood cell could create this discrepancy. The avian red blood cell is oval rather than round, is larger than its mammalian counterpart, and retains its nucleus. ${ }^{18}$ The relatively higher concentration of glucose in avian samples could also affect impedance measurements. ${ }^{19}$ Centrifugal determination of avian packed cell volume may also be more prone to trapped plasma. ${ }^{20}$ Although not determined in this study, the decreased protein expected in Passeriformes (3-5 mg/dL) compared with humans $(6.5-8.0 \mathrm{mg} / \mathrm{dL}$ ) may also affect these values. Determination of hematocrit on the i-STAT appears to require a correction factor for use in Passeriformes. Hemoglobin as determined by the i-STAT system is derived 
Table 4 Venous blood analyte differences in Passerine birds captured on and off the Edwards Plateau

\begin{tabular}{|c|c|c|c|c|c|}
\hline Analyte & Units & $\mathbf{n}$ & Edward's Plateau & Nonplateau & $P$ \\
\hline Chloride & $\mathrm{mmol} / \mathrm{L}$ & $66(38,28)$ & 125.4 (|23.9-|26.9) & $122.6(120.9-124.4)$ & 0.0179 \\
\hline Glucose & $\mathrm{mmol} / \mathrm{L}$ & $86(4 I, 45)$ & $19.68(18.36-21.00)$ & $17.62(16.56-18.37)$ & 0.0162 \\
\hline $\mathrm{HCO}_{3}$ & $\mathrm{mmol} / \mathrm{L}$ & 91 & $22.80(21.65-23.95)$ & $25.43(24.36-26.50)$ & 0.0071 \\
\hline $\mathrm{BE}$ & $\mathrm{mmol} / \mathrm{L}$ & 91 & $0.4(-1.0-1.8)$ & $4.1(2.9-5.3)$ & 0.0002 \\
\hline $\mathrm{pH}$ & $\mathrm{pH}$ & 91 & 7.548 (7.5 I 3-7.583) & 7.604 (7.586-7.623) & 0.0001 \\
\hline $\mathrm{TCO}_{2}$ & $\mathrm{mmol} / \mathrm{L}$ & 91 & $23.6(22.4-24.8)$ & $26.3(25.3-27.4)$ & 0.0008 \\
\hline $\mathrm{pO}_{2}$ & $\mathrm{mmHg}$ & 91 & $36.6(34.9-38.4)$ & $39.4(37.9-40.9)$ & 0.0371 \\
\hline $\mathrm{sO}_{2}$ & $\%$ & 91 & $77.6(74.9-80.3)$ & $83.2(81.5-84.9)$ & 0.0002 \\
\hline
\end{tabular}

Notes: Values expressed as mean and $95 \%$ confidence interval for 34 birds sampled on Edwards Plateau and 57 elsewhere unless otherwise noted. Abbreviations: $\mathrm{BE}$, base excess; $\mathrm{TCO}_{2}$, total $\mathrm{CO}_{2} ; \mathrm{HCO}_{3}$, bicarbonate; $\mathrm{pO}_{2}$, oxygen partial pressure, venous; sO $\mathrm{O}_{2}$, dissolved oxygen, venous.

via a formula which assumes a normal mean corpuscular hemoglobin concentration for humans of $34 \mathrm{mg} / \mathrm{dL}$ :

$$
\text { Hemoglobin }(\mathrm{g} / \mathrm{dL})=\text { hematocrit }(\operatorname{Hct} \%) \times 0.34 \text {. }
$$

Therefore, calculation of hemoglobin is likely incorrect for avian species based on incorrect hematocrit determination as well as an incorrect assumption for mean corpuscular hemoglobin concentration. Mean corpuscular hemoglobin concentration varies widely between avian species but is usually less than that in humans..$^{21,22}$ However, our values for hemoglobin were similar to those previously reported in the titmouse and cardinal, and hemoglobin trends were significant and followed those of hematocrit. ${ }^{15}$ More study is recommended to correct and validate the approximation of hemoglobin for avian species using this analyzer. Although low iron is a characteristic of Edwards Plateau soil, hematocrit, hemoglobin, and packed cell volume were not appreciably affected by the ecoregion. Previous studies have found differences in erythrocyte indices from polluted and nonpolluted zones, but we did not find evidence that these studies controlled for gender or age which could have affected study results and conclusions. ${ }^{22}$ We do not expect that significant changes occurred based on either cellular swelling or lysis in the packed cell volume based on storage of blood for up to 24 hours at room temperature in lithium heparin microhematocrit tubes. ${ }^{23,24}$ However, this phenomenon has

Table 5 Gender-based analyte differences for Passeriformes

\begin{tabular}{lllllll}
\hline Analyte & Units & Gender & Mean & SE & $\boldsymbol{P}$ & $\mathbf{n}$ \\
\hline Hct & Proportion & Female & 0.405 & 0.077 & 0.0234 & 38 \\
& of I & Male & 0.429 & $0.05 \mathrm{I}$ & & 49 \\
$\mathrm{Hgb}$ & $\mathrm{g} / \mathrm{L}$ & Female & 137.6 & 2.62 & $0.027 \mathrm{I}$ & 38 \\
& & Male & 145.6 & 1.77 & & 49 \\
Glucose & $\mathrm{mmol} / \mathrm{L}$ & Female & 18.56 & 0.477 & 0.0122 & 35 \\
& & Male & 17.43 & 0.967 & & 46 \\
\hline
\end{tabular}

Abbreviations: Hct, hematocrit; Hgb, hemoglobin; SE, standard error of the mean. not been specifically studied in Passeriformes and hemolysis was not apparent in our samples. The lack of a seasonal effect on any of the hematologic or other analytes assessed is not surprising because increased hematocrit is classically associated with readiness for migration and winter in Passeriformes, and our sampling was limited to the spring and summer months. ${ }^{5}$

Glucose reported for Passeriformes is generally near $300 \mathrm{mg} / \mathrm{dL}$, and birds sampled in our study proved no exception. ${ }^{6}$ Glucose values were impacted by ecoregion and gender, without apparent effect of species or age. Other studies have also found glucose to be increased in migratory Passeriformes. ${ }^{5}$ Future studies should account for bird origin and avoid use of species where gender is cryptic, or specifically determine gender via genetic or other methods. As a non-normally distributed analyte, glucose may be less amenable to assessment of ecosystem health in Passeriformes. Gender and age were reasonably distributed across samples collected from both ecoregions, so this factor is unlikely to have contributed to the differences seen (Table 1).

Blood urea nitrogen indicates renal function in mammals. In birds, urea is not the primary endpoint for protein catabolism, so it is rarely clinically assessed for renal function and is often below the level of detection. However, many birds had blood urea nitrogen $>3 \mathrm{mg} / \mathrm{dL}(1.07 \mathrm{mmol} / \mathrm{L})$. On physical examination, none of these birds showed clinical signs of dehydration. Blood urea nitrogen can be affected by renal dysfunction, dietary intake, and/or hydration status in birds. Interestingly, blood urea nitrogen was not affected by family, suggesting that dietary protein content did not significantly affect these values in Passeriformes, although most birds sampled were omnivores. Therefore, we suggest that in Passerine birds, blood urea nitrogen should continue to be evaluated as a hydration status indicator, and an assay with a lower limit of detection would likely be of more use in avian species. Because hematocrit and hemoglobin increased and packed cell volume trended towards an increase when 
Table 6 Effect of age on hematologic and venous blood gas analytes in Passeriformes from Texas

\begin{tabular}{|c|c|c|c|c|c|c|c|}
\hline Analyte & Unit & $\begin{array}{l}\text { Total } \\
\text { samples }\end{array}$ & Adult & $\begin{array}{l}\text { Adult } \\
\text { samples }\end{array}$ & Juvenile & $\begin{array}{l}\text { Juvenile } \\
\text { samples }\end{array}$ & $P$ \\
\hline $\mathrm{Hct}$ & Proportion of I & 90 & $0.426(0.4 \mid 4-0.439)^{\mathrm{a}}$ & 55 & $0.403(0.389-0.417)$ & 35 & 0.0048 \\
\hline BE & $\mathrm{mmol} / \mathrm{L}$ & 89 & $3.6(2.3-4.6)$ & 63 & $0.9(-0.9-2.7)$ & 26 & 0.0137 \\
\hline $\mathrm{Hgb}$ & $\mathrm{g} / \mathrm{L}$ & 90 & $145.0(|40.7-| 49.2)^{\mathrm{a}}$ & 55 & $136.8(3|2|-.|4| .5)$ & 35 & 0.0040 \\
\hline $\mathrm{HCO}_{3}$ & $\mathrm{mmol} / \mathrm{L}$ & 89 & $25.22(24.23-26.21)$ & 63 & $22.67(21.2-24.14)$ & 26 & 0.0047 \\
\hline $\mathrm{TCO}_{2}$ & $\mathrm{mmol} / \mathrm{L}$ & 89 & $26.0(25.0-27.0)$ & 63 & $23.7(22.2-25.3)$ & 26 & 0.0147 \\
\hline Lactate & $\mathrm{mmol} / \mathrm{L}$ & 62 & $4.409(4.03 \mid-4.788)$ & 46 & $5.048(4.617-5.478)$ & 16 & 0.0488 \\
\hline
\end{tabular}

Notes: All values given as the mean and $95 \%$ confidence interval. ${ }^{a}$ Denotes non-normal distributions.

Abbreviations: $\mathrm{TCO}_{2}$, total $\mathrm{CO}_{2}$; $\mathrm{Hgb}$, hemoglobin; $\mathrm{BE}$, base excess; $\mathrm{HCO}_{3}$, bicarbonate; Hct, hematocrit.

blood urea nitrogen was greater than $3 \mathrm{mg} / \mathrm{dL}$, we suggest this analyte may be used as a crude indicator of dehydration in Passeriformes. However, further histopathologic or other evaluation of the renal system in these birds was not performed, so renal system disease or dysfunction cannot be ruled out. Blood urea nitrogen was higher in migratory Passerine birds with a lower body condition score than in those with an adequate body condition score. ${ }^{5}$ This finding was attributed to use of body protein in the absence of appropriate fat stores and lack of fat catabolism to create metabolic water resulting in dehydration. In our study, we encountered dehydration based on hematocrit, packed cell volume, and blood urea nitrogen changes, but not based on physical examination, suggesting dehydration may be relatively cryptic in Passeriformes.

Blood concentrations of sodium, potassium, chloride, and ionized calcium may indicate kidney, liver, adrenal, salt gland, or gastrointestinal dysfunction, or dietary intake and environment exposure. Each of the electrolyte concentrations were influenced by avian taxa, while none were affected by age or gender. Only chloride was affected by ecoregion. Differing dietary or other physiologic adaptation of species inhabiting the same ecoregion could account for electrolyte differences based on taxa. Therefore, we suggest electrolytes not be used as indicators of ecologic or population health, except when only a sole taxonomic group or species is studied. In Passeriformes, electrolytes appear to be determined based on taxonomic grouping. However, these values could be used to differentiate further those families wherein taxonomic group is under debate. Chloride was higher in birds captured on the Edwards Plateau. The Edwards aquifer underlies the Edwards Plateau, with water quality ranging from fresh to slightly saline and characterized as hard or high in mineral content. ${ }^{25}$ We suspect the differences in chloride concentrations are based on dietary intake, and the expected parallel changes in sodium concentrations may have been obstructed by taxonomic differences. Despite the relatively high calcium content of the caliche clay and calcium carbonate soils, and mineral content of the hard water sources of this region, we found no differences in ionized calcium based on ecoregion, season, or gender, again suggesting that calcium homeostasis is tightly regulated by Passeriformes.

Reference intervals for lactate concentrations in most birds have not been established. Reference intervals in dogs and cats are generally $<2.0 \mathrm{mmol} / \mathrm{L}$, but in puppies, neonatal humans, baboons, and foals, as well as in flightconditioned birds post flight, this value is much higher (up to $13.3 \mathrm{mmol} / \mathrm{L}$ ). ${ }^{3,26,27}$ Lactate concentration was affected solely by age and did not affect $\mathrm{pH}$ in this study, and no birds suffered lactic acidosis. Higher lactate, lower base excess, bicarbonate, and total $\mathrm{CO}_{2}$ of juvenile birds are likely due to increased work of flight in a juvenile bird with a lower hematocrit and hemoglobin, and less perfusion and oxygenation capacity. Increased exercise in young birds is similar to that of long distance runners during high-intensity training in which lactate concentration is higher initially and then drops corresponding to the increased aerobic capacity

Table 7 Differences in analytes of migratory and nonmigratory Passeriformes

\begin{tabular}{|c|c|c|c|c|c|c|c|c|}
\hline \multirow{2}{*}{$\frac{\text { Analytes }}{\mathrm{TCO}_{2}}$} & \multirow{2}{*}{$\begin{array}{l}\text { Units } \\
\mathrm{mmol} / \mathrm{L}\end{array}$} & \multicolumn{3}{|c|}{ Migrants } & \multicolumn{3}{|c|}{ Nonmigrants } & \multirow{2}{*}{$\begin{array}{l}P \\
0.0285\end{array}$} \\
\hline & & 23.6 & $(22.1-25.1)$ & 22 & 25.9 & $(24.9-26.8)$ & 69 & \\
\hline $\mathrm{HCO}_{3}$ & $\mathrm{mmol} / \mathrm{L}$ & 22.8 & $(21.3-24.3)$ & 22 & 24.97 & $(24.0 \mathrm{I}-25.94)$ & 69 & 0.0409 \\
\hline $\mathrm{pO}_{2}$ & $\mathrm{mmHg}$ & 41.9 & $(38.8-44.9)$ & 22 & 37.9 & $(36.1-38.3)$ & 69 & 0.0032 \\
\hline $\mathrm{sO}_{2}$ & $\%$ & 84.4 & $(81.4-87.3)$ & 22 & 80.1 & $(78.3-81.8)$ & 69 & 0.0339 \\
\hline Sodium & $\mathrm{mmol} / \mathrm{L}$ & 153.9 & $(152.0-155.7)$ & 23 & 157.1 & (I55.9-I58.3) & 69 & 0.0029 \\
\hline Chloride & $\mathrm{mmol} / \mathrm{L}$ & 126.3 & $(124-128.6)$ & 21 & 123.2 & $(122.0-124.5)$ & 45 & 0.0122 \\
\hline
\end{tabular}

Note: Values are given as mean ( $95 \%$ confidence interval) and $\mathrm{n}$.

Abbreviations: $\mathrm{TCO}_{2}$, total $\mathrm{CO}_{2} ; \mathrm{HCO}_{3}$, bicarbonate; $\mathrm{PO}_{2}$, oxygen partial pressure, venous; $\mathrm{sO}_{2}$, dissolved oxygen, venous. 


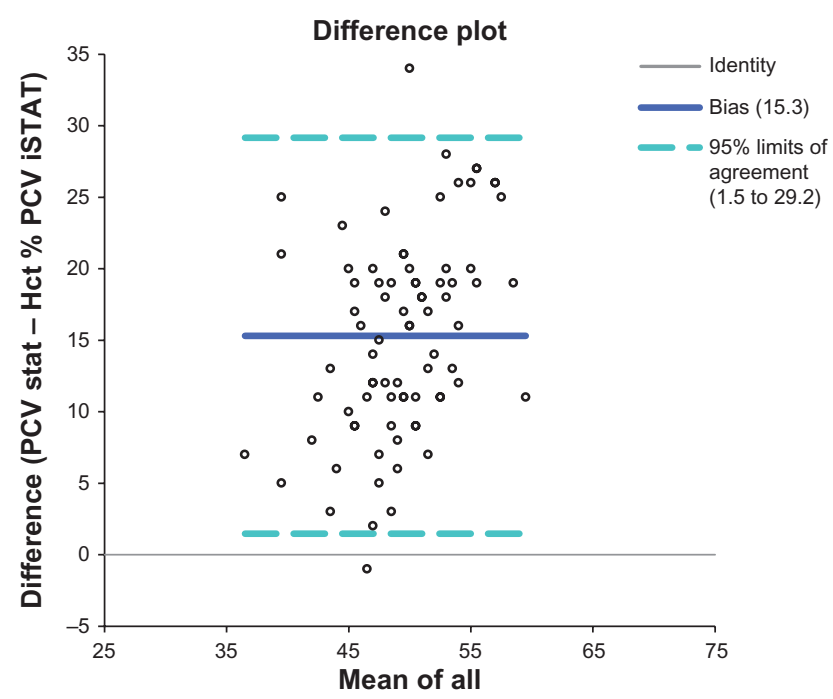

Figure 2 Bland Altman plot of the differences between PCV and Hct for free-living Passeriformes.

Abbreviations: Hct, hematocrit; PCV, packed cell volume.

and better endurance expected of adult birds. ${ }^{28}$ Juvenile birds did not have a lower venous $\mathrm{pO}_{2}$, which would indicate poor tissue oxygen supply, nor did they have lower $\mathrm{pH}$ indicating true lactic acidemia. Lactate may also be increased in the young animal as protection against hypoglycemia, or based on increased struggling during sampling. ${ }^{3}$ However, we did not encounter increased difficulty in sampling juvenile birds, and glucose of juveniles did not differ from adults. Our values for lactate are lower and with smaller ranges than those reported in a similar study of select Passeriformes. ${ }^{7}$ However, differing sample sites, species, and animal handling methods may have resulted in our comparatively decreased values. All samples in this study were obtained from a central venipuncture site, ie, the jugular vein, as recommended for evaluation of venous blood gases and determination of $\mathrm{pH}$. Handling protocols involved removal of birds from the net and placement in opaque well-ventilated cloth bags for transport to the sampling site. Birds remained in the bag until sampling, sometimes for as long as 30 minutes, and were not continuously handled prior to sampling, which may have resulted in less struggling and lower lactate concentrations.

Venous blood $\mathrm{pH}$ and $\mathrm{sO}_{2}$ were affected solely by ecoregion in our study. Venous blood $\mathrm{pH}$ failed to become overtly acidotic, even after temperature correction, in contrast with previous studies. ${ }^{7}$ Hemoglobin saturation, ie, $\mathrm{sO}_{2}$, is calculated from a formula derived from $\mathrm{pO}_{2}, \mathrm{pH}$, and bicarbonate values determined by analyzer. ${ }^{11}$ The validity of this measurement is questionable because values based on those expected for human blood $\mathrm{pH}$ (7.4) are incorporated. However, should one consider values we report as normal, ie, a Passeriform
$\mathrm{pH}$ of about 7.5, the correction factor would be small with or without temperature correction. Arterial $\mathrm{sO}_{2}$ is predicted by venous measurements in human patients with critical conditions, and in dogs, venous blood gases can be superior to arterial ones for assessment of oxygenation and acid base status. ${ }^{29-32}$ In humans not experiencing shock, venous $\mathrm{pH}$, bicarbonate, and base excess are considered clinically interchangeable for arterial values. ${ }^{31,33}$

Birds sampled on the Edwards Plateau are acidotic in comparison with those sampled east of the plateau. The respiratory $\left(\mathrm{pCO}_{2}\right)$ venous blood gases do not differ between ecoregions, while the metabolic aspects (both bicarbonate and base excess) in venous blood of plateau birds are decreased, suggesting that, along with a decreased $\mathrm{pH}$, the acidotic process is likely to be metabolic in origin. If we calculate the anion gap for the means of the birds sampled on and off the plateau:

$$
\begin{aligned}
& \text { Anion gap } \\
& \begin{aligned}
\text { [plateau means }]= & (\mathrm{Na}[156.5]+\mathrm{K}[4.26]) \\
& -\left(\mathrm{Cl}[125.4]+\mathrm{HCO}_{3}[22.80]\right) \\
= & 12.56
\end{aligned}
\end{aligned}
$$

$$
\begin{aligned}
& \text { Anion gap } \\
& \begin{aligned}
{[\text { nonplateau means }]=} & (\mathrm{Na}[156.1]+\mathrm{K}[3.994]) \\
& -(\mathrm{Cl}[122.6]+\mathrm{HCO} 3[25.43]) \\
= & 4.076 .
\end{aligned}
\end{aligned}
$$

While the anion gap for Passeriformes has not been reported before, our values are similar to that reported for cats, dogs, or humans for those on the plateau but lower for those not sampled on the plateau. Birds sampled from the Edwards Plateau also have higher chloride concentrations. Taken together, these abnormalities are referable to a population suffering hyperchloremic metabolic acidosis. Hyperchloremic metabolic acidosis can be due to a number of factors, including renal loss of bicarbonate, gastrointestinal loss of bicarbonate (diarrhea, vomiting), or from dilutional acidosis based on administration of a large volume of saline. The Edwards Plateau is now dominated by poor quality browse and forb plants, particularly Ashe juniper (Juniperus ashei), commonly called cedar breaks, with little plant diversity. We suggest that aquifer salinity of the plateau as well as the Texas cedar's tolerance to salt are factors which may have created and maintained a high salinity environment. Relatively high dietary intake of $\mathrm{NaCl}$ has caused a mild metabolic acidosis, compensated for by bicarbonate to offset the acid base shift of hyperchloremia. Birds in this area have abundant access to bicarbonate, a primary component of the clay soils in the region. Based on 
our findings, relative to the same families of birds sampled in other areas, we suggest that the population is compensating for a degraded ecosystem in a relatively recent evolutionary time scale. Overgrazing began in this area coincident with settlement of Europeans in the mid 1800s and resulted in a loss of ecosystem diversity based on overgrazing and suppression by fire by the $1940 \mathrm{~s} .{ }^{34}$ Because many of the bird species sampled here have small home ranges throughout their lifetime, they indicate evolutionarily recent changes to this ecosystem.

Venous $\mathrm{pO}_{2}$ and $\mathrm{sO}_{2}$ were lower in birds sampled on the Edwards Plateau. Venous $\mathrm{pCO}_{2}$ has poor and unpredictable agreement with arterial values in human patients, and was not affected by age, gender, ecoregion, time of day, or family in our study. ${ }^{31,33}$ Venous $\mathrm{pO}_{2}$ is dependent on oxygen delivery to and consumption by the tissues, and can change according to cardiac function, lung function, hematocrit or packed cell volume, oxygenation, tissue metabolic rate, cellular oxygen use, and sample site. Hemoglobin, hematocrit, and packed cell volume were not significantly different in birds on the Edwards Plateau. Elevation of the Edwards Plateau varies from $100 \mathrm{~m}$ to $1000 \mathrm{~m}$, while elevations in the eastern areas sampled are generally less than $400 \mathrm{~m}$, although oxygen availability does not appear to be significantly different. In humans, changes in venous $\mathrm{pO}_{2}$ and hemoglobin saturation based on elevation generally do not occur until around $2500 \mathrm{~m}$, and again we do not expect this minimal elevation would result in blood gas changes in Passeriformes. ${ }^{35} \mathrm{We}$ suggest that birds are experiencing metabolic acidosis, resulting in differing tissue metabolic rates or cellular use of oxygen and lower venous oxygen values. The locations at which we sampled birds were apparently unpolluted and located outside of small townships. Venous $\mathrm{pCO}_{2}, \mathrm{sO}_{2}$, and $\mathrm{pO}_{2}$ merit further investigation as indicators of respiratory function in birds exposed to pollution. Although iron deficiency is common in soil of the Edwards Plateau, venous dissolved oxygen was the only hematologic variable found to be lower in plateau birds.

We found no evidence of seasonal change in any analyte, in contrast with previous studies of enzymes and hematologic parameters in Passeriformes. However, birds were not trapped and sampled year round. 5,36

Based on our study, Passeriformes can act as a reference population for the analytes tested, and the iSTAT system appears useful based on the intervals created. However, analyte variability may be reduced by limiting the genera of birds included and controlling for age, gender, and migratory life history. While variability in hematocrit underestimated packed cell volume, variability in the hematocrit range was less. Red blood cell analytes were affected by the most variables, glucose was affected by multiple variables, and electrolytes were impacted by taxon. Blood gas and acid base status analytes were the least affected by gender, age, and taxon, and were mainly affected by ecoregion, which had suffered evolutionarily recent ecologic degradation. Further investigation of the i-STAT system to assess ecologic health, and Passeriform populations in polluted, degraded, or heavily ecosystems could be sampled and compared with birds sampled in more pristine ecosystems. While birds in this study were collected after sampling, this system requires a small sample volume within safe live bird sampling limits for many small species.

\section{Acknowledgments}

We thank the Schubot Exotic Bird Health Center and the FC Dezendorf Trust, New Wells Point Partners, and the Allen, Biesele, Decker, Ellis, Evancho, Fehrenkamp, Kelsay, Mollo, Panak, Rivera, Simons, Smith, Tyler, Verser, Wiggins, and especially the Kensinger and Willis families for support and land access for Texas Ecolabs. This is publication number 1449 of the Biodiversity Research and Teaching Collections at Texas A\&M University.

\section{Disclosure}

The authors report no conflicts of interest in this work.

\section{References}

1. Deem SL, Parker PG, Cruz MB, et al. Comparison of blood values and health status of Floreana Mockingbirds (Mimus trifasciatus) on the islands of Champion and Gardner-by-Floreana, Galapagos Islands. J Wildl Dis. 2011;47:94-106.

2. Fokidis HB, Greiner EC, Deviche P. Interspecific variation in avian blood parasites and haematology associated with urbanization in a desert habitat. J Avian Biol. 2008;39:300-310.

3. McMichael M, Lees GE, Hennessey J, et al. Serial plasma lactate concentrations in 68 puppies aged 4 to 80 days. J Vet Emerg Crit Care (San Antonio). 2005;15:17-21.

4. Nyholm NEI. Influence of heavy metal exposure during different phases of the ontogeny on the development of pied flycatchers, Ficedula hypoleuca, in natural populations. Arch Environ Contam Toxicol. 1998;35: 632-637.

5. Bairlein F, Totzke U. New aspects on migratory physiology of transSaharan Passerine migrants. Ornis Scand. 1992;23:244-250.

6. Fokidis HB, Hurley L, Rogowski C, et al. Effects of captivity and body condition on plasma corticosterone, locomotor behavior, and plasma metabolites in curve-billed thrashers. Physiol Biochem Zool. 2011;84: 595-606.

7. Harms CA, Harms RV. Venous blood gas and lactate values of mourning doves (Zenaida macroura), boat-tailed grackles (Quiscalus major), and house sparrows (Passer domesticus) after capture by mist net, banding, and venipuncture. J Zoo Wildl Med. 2012;43:77-84.

8. Martin MP, Wineland M, Barnes HJ. Selected blood chemistry and gas reference ranges for broiler breeders using the i-STAT handheld clinical analyzer. Avian Dis. 2010;54:1016-1020. 
9. Paula VV, Fantoni DT, Otsuki DA, et al. Blood-gas and electrolyte values for Amazon parrots (Amazona aestiva). Pesq Vet Bras. 2008;28: 108-112. Portuguese.

10. Steinmetz HW, Vogt R, Kastner S, et al. Evaluation of the i-STAT portable clinical analyzer in chickens (Gallus gallus). JVet Diagn Invest. 2007; 19:382-388.

11. iSTAT-1 system manual. Abbot Park, IL: Abbott Point of Care Inc; 2012.

12. Tully T. Birds. In: Mitchell M, Tully T, editors. Manual of Exotic Pet Practice. Philadelphia, PA: Saunders; 2009.

13. Prinzinger R, Pressmar A, Schleucher E. Body-temperature in birds. Comp Biochem Physiol A Physiol. 1991;99:499-506.

14. Poole A. Birds of North America Online. In: Poole A, editor. Ithaca, NY: Cornell Laboratory of Ornithology; 2005.

15. Nice LB, Nice MM, Kraf RM. Erythrocytes and hemoglobin in the blood of some American birds. Wilson Bull. 1935;47:120-124.

16. Archawaranon M. Captive Hill Mynah Gracula religiosa breeding success: potential for bird conservation in Thailand? Bird Conserv Int. 2005; 15:327-335.

17. Norte AC, Ramos JA, Sousa JP, et al. Variation of adult Great Tit Parus major body condition and blood parameters in relation to sex, age, year and season. J Ornithol. 2009;150:651-660.

18. Clark P, Boardman W, Raidal S. General hematological characteristics of birds. In: Atlas of Clinical Avian Hematology. Hoboken, NJ: Wiley; 2009.

19. Guevara E, Gonzalez F. Prediction of glucose concentration by impedance phase measurements. Presented at the Tenth Mexican Symposium on Medical Physics, Mexico City, ME, March 17-19, 2008.

20. Ferrando A, Bobadilla IG, Bobadilla MS, et al. Comparative estimation of hematocrit and trapped plasma in the packed cell-volume in man, rabbit and chicken blood. Comp Biochem Physiol A Physiol. 1981;70: 611-613.

21. Glomski C, Pica A. The Avian Eyrthrocyte: Its Phylogenetic Odyssey. Enfield, NH: Science Publishers; 2011.

22. Llacuna S, Gorriz A, Riera M, et al. Effects of air pollution on hematological parameters in passerine birds. Arch Environ Contam Toxicol. 1996;31:148-152.

23. Harr KE, Raskin RE, Heard DJ. Temporal effects of 3 commonly used anticoagulants on hematologic and biochemical variables in blood samples from macaws and Burmese pythons. Vet Clin Pathol. 2005;34: 383-388.
24. Hattingh J, Smith EM. Anticoagulants for avian and reptilian blood: heparin and EDTA. Pflugers Arch. 1976;363:267-269.

25. Eckhardt G. The Edwards Aquifer Website. Edwards Water Quality, 1995-2013. Available from: http://www.edwardsaquifer.net/geology. html.

26. Chaplin S, Meuller L, Degernes L. Physiological assessment of rehabilitated raptors prior to release. In: Redig P, Cooper J, Remple J, et al, editors. Raptor Biomedicine. Minneapolis, MN: University of Minnesota Press; 1993.

27. Holz PH, Naisbitt R, Mansell P. Fitness level as a determining factor in the survival of rehabilitated peregrine falcons (Falco peregrinus) and brown goshawks (Accipiter fasciatus) released back into the wild. $J$ Avian Med Surg. 2006;20:15-20.

28. Acevedo EO, Goldfarb AH. Increased training intensity effects on plasma lactate, ventilatory threshold, and endurance. Med Sci Sports Exerc. 1989;21:563-568.

29. Ak A, Ogun CO, Bayir A, et al. Prediction of arterial blood gas values from venous blood gas values in patients with acute exacerbation of chronic obstructive pulmonary disease. Tohoku J Exp Med. 2006;210: 285-290.

30. Gennis PR, Skovron ML, Aronson ST, et al. The usefulness of peripheral venous blood in estimating acid-base status in acutely ill patients. Ann Emerg Med. 1985;14:845-849.

31. Kirubakaran C, Gnananayagam JE, Sundaravalli EK. Comparison of blood gas values in arterial and venous blood. Indian J Pediatr. 2003;70:781-785

32. Mathias DW, Clifford PS, Klopfenstein HS. Mixed venous blood gases are superior to arterial blood gases in assessing acid-base status and oxygenation during acute cardiac tamponade in dogs. J Clin Invest. 1988;82:833-838.

33. Kelly AM. Review article: can venous blood gas analysis replace arterial in emergency medical care. Emerg Med Australas. 2010;22:493-498.

34. Jordan-Bychkov T. German Seed in Texas Soil: Immigrant Farmers in Nineteenth-Century Texas. Austin, TX: University of Texas Press; 1966.

35. Moore LG. Comparative human ventilatory adaptation to high altitude. Respir Physiol. 2000;121:257-276.

36. Hill EF, Murray HC. Seasonal variation in diagnostic enzymes and biochemical constituents of captive northern Bobwhites and Passerines. Comp Biochem Physiol B Biochem Mol Biol. 1987;87:933-940.
Veterinary Medicine: Research and Reports

\section{Publish your work in this journal}

Veterinary Medicine: Research and Reports is an international, peer-reviewed, open access journal publishing original research, case reports, editorials, reviews and commentaries on all areas of veterinary medicine. The manuscript management system is completely online and includes a very quick and fair peer-review system.

\section{Dovepress}

Visit http://www.dovepress.com/testimonials.php to read real quotes from published authors. 